\title{
Mediastinal paragangliomas related to SDHx gene mutations
}

\author{
Ilona Michałowska1, Jarosław Ćwikła ${ }^{2}$, Aleksander Prejbisz ${ }^{3}$, Paweł Kwiatek ${ }^{1}$, Małgorzata Szperl ${ }^{4}$, \\ Wojciech Michalski ${ }^{5}$, Lucjan Wyrwicz ${ }^{5,6}$, Mariusz Kuśmierczyk ${ }^{7}$, Andrzej Januszewicz $^{3}$, Anna Maciejczyk ${ }^{4}$, \\ Marta Roszczynko ${ }^{4}$, Mariola Pęczkowska ${ }^{3}$
}

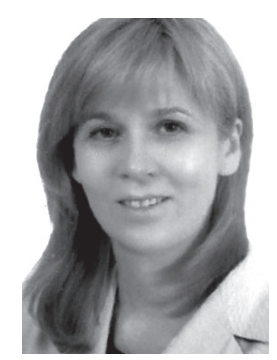

\author{
${ }^{1}$ Department of Radiology, Institute of Cardiology, Warsaw, Poland \\ ${ }^{2}$ Department of Nuclear Medicine, Faculty of Medical Science, University of Warmia, Olsztyn, Poland \\ ${ }^{3}$ Department of Hypertension, Institute of Cardiology, Warsaw, Poland \\ ${ }^{4}$ Laboratory of Molecular Biology, Institute of Cardiology, Warsaw, Poland \\ ${ }^{5}$ Bioinformatics and Biostatistics Unit, The Maria Skłodowska-Curie Memorial Cancer Center and Institute of Oncology, \\ Warsaw, Poland \\ ${ }^{6}$ Department of Gastrointestinal Cancer, The Maria Skłodowska-Curie Memorial Cancer Center and Institute of Oncology, \\ Warsaw, Poland \\ ${ }^{7}$ Department of Cardiac Surgery and Transplantology, Institute of Cardiology, Warsaw, Poland
}

Kardiochirurgia i Torakochirurgia Polska 2016; 13 (3): 276-282

\begin{abstract}
Introduction: Paragangliomas (PGLs) related to hereditary syndromes are rare mediastinal tumors. Paragangliomas are caused by mutations in genes encoding subunits of succinate dehydrogenase enzyme (SDH).

Aim: To evaluate clinical, anatomical and functional characteristics of mediastinal paragangliomas related to $S D H x$ gene mutations.

Material and methods: Retrospective analysis of 75 patients with confirmed $S D H x$ gene mutations (24 patients with $S D H B$, 5 SDHC, 46 with SDHD mutations) was performed. Patients underwent evaluation using computed tomography (CT), somatostatin receptor scintigraphy (SRS) ${ }^{99 \mathrm{~m}} \mathrm{Tc}$-[HYNIC,Tyr3]-octreotide), ${ }^{123}$ I mIBG scintigraphy and urinary excretion of total methoxycatecholamines.

Results: Out of 75 patients, 16 (21\%) patients (1 SDHB, 15 SDHD mutations) had 17 PGLs localized in the mediastinum. Fourteen PGLs were localized in the middle mediastinum (intrapericardial) and 3 PGLs in the posterior mediastinum. The median diameter of paragangliomas measured on the axial slice was $24.3 \mathrm{~mm}$ (interquartile range (IQR): 14.7-36.6), and the median volume was $2.78 \mathrm{ml}$ (IQR: $0.87-16.16)$. Twelve out of 16 patients (75\%) underwent SRS, and 11 of them (92.3\%) had pathological uptake of the radiotracer. Eleven (68.75\%) out of 16 patients underwent 123 I mIBG, with only 3 positive results. Symptoms of catecholamine excretion were observed in 3 patients with PGLs localized in the posterior mediastinum. All PGLs were benign except in 1 patient with the SDHB mutation and PGL detected in the posterior mediastinum, who had a metastatic disease.
\end{abstract}

\section{Streszczenie}

Wstęp: Przyzwojaki uwarunkowane genetycznie należą do rzadkich guzów śródpiersia. Mogą być spowodowane mutacjami genów kodujących podjednostki enzymu dehydrogenazy bursztynianowej (SDH).

Cel: Kliniczna, anatomiczna i czynnościowa charakterystyka przyzwojaków zlokalizowanych w śródpiersiu u pacjentów z mutacją genu SDHX.

Materiał i metody: Retrospektywnej analizie poddano 75 pacjentów z potwierdzoną mutacją genu SDHx (24 pacjentów z mutacją SDHB, 5 z SDHC, 46 z SDHD). U pacjentów wykonano tomografię komputerową, scyntygrafię receptorów somatostatynowych - SRS ( ${ }^{99 m}$ Tc-[HYNIC,Tyr3]-Octreotide) - i scyntygrafię ${ }^{123}$ I mIBG oraz oznaczono stężenie metoksykatecholamin w dobowej zbiórce moczu.

Wyniki: Spośród 75 pacjentów z mutacją genu SDHx u 16 (21\%) pacjentów (15 z mutacją SDHD, 1 z SDHB) stwierdzono 17 przyzwojaków zlokalizowanych w śródpiersiu, 14 przyzwojaków było położonych w śródpiersiu środkowym, wewnątrzosierdziowo, 3 w śródpiersiu tylnym. Mediana wymiaru guza mierzona na przekroju poprzecznym wynosiła $24,3 \mathrm{~mm}$ (rozstęp międzykwartylowy (IQR): 14,7-36,6), a mediana objętości guza 2,78 ml (IQR: 0,87-16,16). U 12 (75\%) pacjentów wykonano SRS, w 11 (92,3\%) przypadkach stwierdzono patologiczne gromadzenie radioznacznika. U 11 (68,75\%) pacjentów przeprowadzono scyntygrafię ${ }^{123}$ I mIBG, patologiczne gromadzenie radioznacznika stwierdzono w 3 przypadkach. Objawy kliniczne związane z wydzielaniem hormonów występowały u 3 chorych z przyzwojakami położonymi w śródpiersiu tylnym. Wszystkie przyzwojaki położone w śródpiersiu były zmianami łagodnymi, z wyjątkiem 1 pacjen-

Address for correspondence: Ilona Michałowska MD, Department of Radiology, Institute of Cardiology, 42 Alpejska St, 04-628 Warsaw, Poland, phone: +48 2234341 68, e-mail: ilonamich@wp.pl

Received: 22.06.2016, accepted: 9.08.2016. 
Conclusions: Most mediastinal paragangliomas were related to SDHD gene mutations. They were asymptomatic, localized in the medial mediastinum, intrapericardially.

Key words: mediastinal paraganglioma, paraganglioma-pheochromocytoma syndromes, SDHx gene mutations.

\section{Introduction}

Mediastinal paragangliomas are rare neuroendocrine tumors/neoplasms deriving from the autonomic nervous system. Paragangliomas (PGLs) may occur as sporadic tumors or be related to hereditary syndromes (at least onethird of all patients with PGLs) [1].

Most cases of familial paragangliomas are caused by mutations in the genes encoding A, B, C, D subunits of mitochondrial complex II enzyme succinate dehydrogenase $(\mathrm{SDH})$ [2]. Predominantly, PGL syndromes are associated with $S D H D$ and $S D H B$ mutations. SDHC mutation is rare, and typically patients have benign, solitary head and neck paragangliomas [3]. SDHD mutation carriers most frequently develop multifocal head and neck paragangliomas; adrenal and extraadrenal PGLs occur less frequently $[2,4]$. $S D H B$ mutation carriers are at risk of malignant and extraadrenal abdominal and thoracic paragangliomas [4, 5].

Mediastinal paragangliomas are rare, accounting for about $2 \%$ of all paragangliomas [6].

Paragangliomas located in the medial mediastinum arise from paraganglia in the region of the cardiac plexus [7]. The PGLs localized in the proximity of the ductus arteriosus, the main pulmonary artery and its bifurcation and the adjacent aortic arch are termed "aortic body tumors, aorticopulmonary or aortopulmonary paragangliomas" [8]. Aortopulmonary paragangliomas are usually asymptomatic [9].

Less commonly, the paragangliomas are located in the posterior mediastinum and arise from the para-vertebral sympathetic chain ganglia. About $50 \%$ of posterior mediastinal paragangliomas are functional [10].

Symptoms of paragangliomas usually are associated with mass effect or hypersecretion of catecholamines. Clinical symptoms related to catecholamine hypersecretion include hypertension, headaches, palpitations, and sweating. The biochemical diagnosis is based on demonstration of an increased level of catecholamine metabolites in plasma and/or urine $[1,4,5]$.

Some reports have suggested that mediastinal paragangliomas often have an aggressive course and patients should be carefully followed up $[6,11]$.

Surgical treatment is considered to be the gold standard in the treatment of thoracic paragangliomas [12], but it may be a challenge. Precise information about localization and relation to other anatomical structures is required before taking the treatment decision.

Paraganglioma diagnosis is based on anatomical and functional examinations. Computed tomography (CT) and ta z mutacją genu SDHB i przyzwojakiem w śródpiersiu tylnym, u którego stwierdzono uogólnienie procesu nowotworowego. Wnioski: Przyzwojaki śródpiersiowe najczęściej występują u pacjentów z mutacją genu SDHD. W większości przypadków są bezobjawowe klinicznie i położone w śródpiersiu środkowym wewnątrzosierdziowo.

Słowa kluczowe: przyzwojaki śródpiersia, zespół paraganglioma-pheochromocytoma, mutacja genu SDHX.

magnetic resonance imaging (MRI) are used as anatomical methods and ${ }^{123}$-metaiodobenzylguanidine scintigraphy ( $\mathrm{mIBG)}$ ) and somatostatin receptor scintigraphy (SRS) as functional methods in the detection of paragangliomas [13-15].

\section{Aim}

The aim of the study was to evaluate clinical, biochemical and imaging characteristics of mediastinal paragangliomas related to $S D H x$ gene mutations.

\section{Material and methods}

We retrospectively analyzed the patients with $S D H x$ mutations confirmed by genetic testing and registered in the Polish Pheochromocytoma-Paraganglioma Registry. Carriers of SDHx germline mutations (both index cases and their relatives) underwent evaluation of the head and neck, the thorax, the abdomen and the pelvis using computed tomography $(\mathrm{CT})$ and the level of daily urinary excretion of total methoxycatecholamines was determined.

The protocol for this study was approved by the local ethics committee. Exclusion criteria were a refusal or inability to understand or sign the informed consent, contraindications to administer iodate contrast material, being pregnant or lactating women. All patients signed the informed consent before participating in the study.

Overall, 75 patients were enrolled in the study (24 patients with $S D H B$ mutations, 5 with $S D H C, 46$ with $S D H D$ mutations); 16 patients had PGLs localized in the mediastinum. The CT examinations were performed using a dual source scanner (Somatom Definition, Somatom Definition Flash, Siemens Medical Solutions, Erlangen, Germany) after contrast administration.

The slice thickness was $1 \mathrm{~mm}$, tube voltage was set at 80-120 kV, tube current 165-210 mA, depending on scanning regions and body size.

Highly iodinated contrast material ( $\geq 350 \mathrm{mg} / \mathrm{ml}$ ) was administered in the antecubital vein in the amount of 80-100 $\mathrm{ml}$ (depending on the body size) at a flow rate of $4-5 \mathrm{ml} / \mathrm{s}$. The scans were done in the arterial phase $30 \mathrm{~s}$ after contrast injection. The images were reconstructed with a standard soft-tissue-kernel algorithm.

Six out of 16 patients underwent CT examinations outside our department before the surgery.

A well-defined soft tissue mass with typical high enhancement after i.v. contrast agent administration was recognized as a paraganglioma [16]. Based on CT exami- 
nations, localization of paragangliomas, relation to other anatomical structures, invasion of the adjacent structures, their dimension and volume were analyzed.

Mediastinal paragangliomas were divided into tumors localized in the anterior, middle or posterior mediastinum. Paragangliomas associated with the heart were classified as intrapericardial or intracardiac PGLS.

According to the World Health Organization, the criterion for the diagnosis of malignant pheochromocytoma or PGL was the presence of metastases [17].

Carriers of the $\mathrm{SDH} x$ gene mutations with paragangliomas detected by CT examination were subsequently screened by somatostatin receptor scintigraphy (SRS) and mIBG scintigraphy as additional functional imaging modalities.

SRS was performed using ${ }^{99 \mathrm{~m} T c-[H Y N I C, T y r 3]-o c t r e o-}$ tide ${ }^{99 \mathrm{~m} T c}$ [TOC] (600-700 MBq) (Tektrotyd; National Center For Nuclear Research-Polatom; Poland). The detailed method of kit labeling with ${ }^{99 \mathrm{~m} T \mathrm{~T}}$ was presented previously [18]. Images were acquired between 1 and 3 hours after the i.v. injection of a radiotracer using a double-head camera. The acquisition of head, neck, chest, abdominal and pelvis images was performed using the whole-body single photon emission computed tomography (WB-SPECT) method.

A $^{123}$ I mIBG (AdreView, GE Healthcare; USA) study was performed in 11 patients. In each case after thyroid suppression using Lugol's solution, one day before the study, the patients received an injection of 300-370 MBq of ${ }^{123}$ I mIBG. Images were acquired between 18 and 22 hours after the i.v. injection of the radiotracer using a double-head camera. The acquisition of head, neck, chest, abdominal and pelvis images was performed using the same method as with SRS - whole-body SPECT.

As with SRS, any focal or diffuse nonphysiological accumulation observed during the examination was reported as pathological. Diffuse low-activity intestinal uptake (with SRS) or liver and heart uptake (with mIBG) was rated as nonspecific, physiologic uptake.

\section{Statistical analysis}

Due to the non-normal distribution of most data, the results are presented as median and interquartile range (IQR). Frequency and percentages were reported for categorical variables. Statistical analysis was performed using IBM SPSS 20 for Linux (IBM SPSS Inc, Chicago, IL; USA).

\section{Results}

Out of 75 patients, 16 (21\%) patients (15 SDHD, 1 SDHB) had paragangliomas localized in the mediastinum. Altogether 207 paragangliomas were detected in different regions, 17 (8.2\%) of which were localized in the mediastinum.

All patients with SDHD mutations, except 1, had a C11X nonsense mutation, which was recognized as a founding mutation [17], and 1 patient had an exon deletion. In 1 SDHB carrier, we observed a missense mutation.

The median age was 37 years (IQR: 28.25-46.75). The male to female ratio was $1: 1$.
One patient with SDHB mutation had a malignant disease with metastasis to the lung, bone and lymph nodes. Table I contains patients' characteristics and tumor localizations.

\section{Localization of paragangliomas}

Fourteen paragangliomas were localized in the middle mediastinum and 3 PGLs in the posterior mediastinum. None of the PGLs was localized in the anterior mediastinum.

All medial mediastinal paragangliomas were localized intrapericardially; no paragangliomas had an intracardiac localization. Five paragangliomas were localized in the aortopulmonary window (Figs. 1 A, B), and in 4 cases paragangliomas were localized in the proximity of the coronary arteries (3 close to the left descending artery, 1 close to the right coronary artery) (Figs. 2, 3). A single paraganglioma was localized near the aortic arch, 2 between the left atrium and the right pulmonary artery (Figs. 4 A, B) and 2 among the vena cava superior (VCS), the ascending aorta and the trachea. We did not observe any signs of PGL invasion of the adjacent structures.

The median diameter of paragangliomas measured on the axial slice was $24.3 \mathrm{~mm}$ (IQR: 14.7-36.6), and the median volume was $2.78 \mathrm{ml}$ (IQR: 0.87-16.16).

The arterial phase images obtained in 14/17 paragangliomas showed a median tumor attenuation of $165 \mathrm{HU}$ (IQR: 141-187).

Twelve (75\%) out of 16 patients underwent SRS, 11 of whom (92.3\%) had pathological uptake of the radiotracer in the mediastinal PGLs.

Eleven (68.75\%) out of 16 patients underwent ${ }^{123}$ I mIBG, with only 3 positive results in mediastinal PGLS.

All patients had multifocal paragangliomas, 14/16 were localized in the head and neck region, 6/16 extraadrenal PGLs were localized in the abdomen, and 4 patients had a history of pheochromocytomas.

\section{Symptoms}

Symptoms of catecholamine excess were present in only 3 patients, with paragangliomas localized in the posterior mediastinum, and after surgical treatment the level of catecholamines was normal. All patients with middle mediastinum tumors were asymptomatic.

\section{Treatment}

Eight (50\%) patients underwent surgical treatment, 5 patients with paragangliomas localized in the middle mediastinum (1 patient had surgical resection of 2 mediastinal paragangliomas) and 3 patients with PGLs localized in the posterior mediastinum. Three patients with PGLs localized in the middle mediastinum required subsequent surgery due to intraoperative complications of the tumor resection. None of the patients died due to intra- or postoperative complications.

One patient with a middle mediastinum PGL underwent surgery with additional radiotherapy. All resected tumors 
Tab. I. Characteristics of patients and localizations of tumors

\begin{tabular}{|c|c|c|c|c|c|c|c|c|c|c|c|c|}
\hline 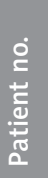 & 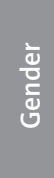 & 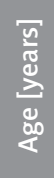 & 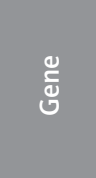 & 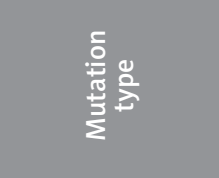 & 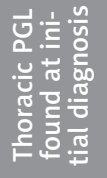 & 흘율 & 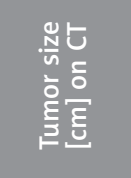 & 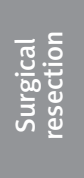 & 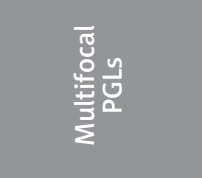 & 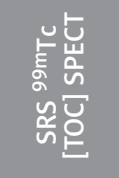 & 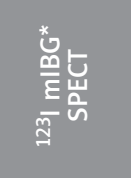 & 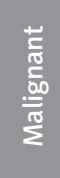 \\
\hline 1 & $\mathrm{~F}$ & 48 & SDHD & $\begin{array}{c}\text { Exon 1, c. } 33 \mathrm{C}>\mathrm{A} \text {, } \\
\text { p. C11X } \\
\text { Nonsense }\end{array}$ & No & $\begin{array}{l}\text { Posterior } \\
\text { mediastinum } \\
\text { Th2-Th3 }\end{array}$ & $2 \times 2.3$ & Yes & $\begin{array}{l}\text { Yes } \\
\text { HNP, pheo, } \\
\text { abdomen } \\
\text { extraadrenal }\end{array}$ & Positive & Positive & No \\
\hline 2 & $\mathrm{~F}$ & 43 & SDHD & Exon 1 deletion & No & $\begin{array}{l}\text { Middle mediastinum } \\
\text { (between LA, right } \\
\text { pulmonary artery, } \\
\text { ascending aorta) }\end{array}$ & $4.5 \times 3.5$ & Yes & $\begin{array}{c}\text { Yes } \\
\text { Abdomen } \\
\text { extraadrenal }\end{array}$ & Positive & Positive & No \\
\hline 3 & $M$ & 30 & SDHD & $\begin{array}{c}\text { Exon 1, c. } 33 \mathrm{C}>\mathrm{A} \text {, } \\
\text { p. C11X } \\
\text { Nonsense }\end{array}$ & No & $\begin{array}{l}\text { Middle mediastinum } \\
\text { (between aortic root, } \\
\text { pulmonary trunk } \\
\text { and LAD) }\end{array}$ & $1.6 \times 1.3$ & No & $\begin{array}{c}\text { Yes } \\
\text { HNP, pheo }\end{array}$ & Positive & Negative & No \\
\hline 4 & $\mathrm{~F}$ & 39 & SDHD & $\begin{array}{c}\text { Exon 1, c.33C>A, } \\
\text { p. C11X } \\
\text { Nonsense }\end{array}$ & No & $\begin{array}{l}\text { Middle mediastinum } \\
\text { (between aortic root, } \\
\text { pulmonary trunk } \\
\text { and LAD) }\end{array}$ & $1.3 \times 1.2$ & No & $\begin{array}{c}\text { Yes } \\
\text { HNP, pheo, } \\
\text { abdomen } \\
\text { extraadrenal }\end{array}$ & Positive & Negative & No \\
\hline 5 & $M$ & 59 & SDHD & $\begin{array}{c}\text { Exon 1, c. } 33 \mathrm{C}>\mathrm{A}, \\
\text { p. C11X } \\
\text { Nonsense }\end{array}$ & No & $\begin{array}{l}\text { Middle mediastinum } \\
\text { (aortopulmonary } \\
\text { window) }\end{array}$ & $2.1 \times 1.8$ & No & $\begin{array}{l}\text { Yes } \\
\text { HNP }\end{array}$ & Positive & Negative & No \\
\hline 6 & $\mathrm{~F}$ & 40 & SDHD & $\begin{array}{c}\text { Exon 1, c. } 33 \mathrm{C}>\mathrm{A} \text {, } \\
\text { p. C11X } \\
\text { Nonsense }\end{array}$ & No & $\begin{array}{l}\text { Middle mediastinum } \\
\text { (between LA and } \\
\text { descending aorta) }\end{array}$ & $3.7 \times 2.0$ & Yes & $\begin{array}{c}\text { Yes } \\
\text { HNP, abdomen } \\
\text { extraadrenal }\end{array}$ & Positive & ND & No \\
\hline 7 & $\mathrm{~F}$ & 34 & SDHD & $\begin{array}{c}\text { Exon 1, c.33C>A, } \\
\text { p. C11X } \\
\text { Nonsense }\end{array}$ & No & $\begin{array}{c}\text { Middle mediastinum } \\
\text { (between right pulmonary } \\
\text { artery and LA) } \\
\text { Middle mediastinum } \\
\text { (aortopulmonary window) }\end{array}$ & $2.7 \times 3.5$ & Yes & $\begin{array}{c}\text { Yes } \\
\text { HNP, abdomen } \\
\text { extraadrenal }\end{array}$ & $\begin{array}{l}\text { Positive } \\
\text { Positive }\end{array}$ & $\begin{array}{l}\text { Negative } \\
\text { Negative }\end{array}$ & No \\
\hline 8 & $M$ & 33 & SDHD & $\begin{array}{c}\text { Exon 1, c.33C>A, } \\
\text { p. C11X } \\
\text { Nonsense }\end{array}$ & No & $\begin{array}{l}\text { Middle mediastinum } \\
\text { (aortopulmonary window) }\end{array}$ & $2.5 \times 1.7$ & No & $\begin{array}{c}\text { Yes } \\
\text { HNP, pheo }\end{array}$ & Positive & Negative & No \\
\hline 9 & $M$ & 64 & SDHD & $\begin{array}{c}\text { Exon 1, c. } 33 \mathrm{C}>\mathrm{A} \text {, } \\
\text { p. C11X } \\
\text { Nonsense }\end{array}$ & No & $\begin{array}{l}\text { Middle mediastinum } \\
\text { (between VCS, ascending } \\
\text { aorta, right pulmonary } \\
\text { artery and trachea) }\end{array}$ & $3 \times 2$ & Yes & $\begin{array}{l}\text { Yes } \\
\text { HNP }\end{array}$ & ND & ND & No \\
\hline 10 & M & 28 & SDHD & $\begin{array}{c}\text { Exon 1, c. } 33 \mathrm{C}>\mathrm{A} \text {, } \\
\text { p. C11X } \\
\text { Nonsense }\end{array}$ & No & $\begin{array}{l}\text { Middle mediastinum } \\
\text { (aortic pulmonary } \\
\text { window) }\end{array}$ & $1.5 \times 1.6$ & No & $\begin{array}{l}\text { Yes } \\
\text { HNP }\end{array}$ & Positive & Negative & No \\
\hline 11 & $M$ & 26 & SDHD & $\begin{array}{c}\text { Exon 1, c. } 33 \mathrm{C}>\mathrm{A} \text {, } \\
\text { p. C11X } \\
\text { Nonsense }\end{array}$ & No & $\begin{array}{l}\text { Middle mediastinum } \\
\text { (right atrioventricular } \\
\text { groove near RCA) }\end{array}$ & $3.6 \times 2.3$ & No & $\begin{array}{l}\text { Yes } \\
\text { HNP }\end{array}$ & Positive & Negative & No \\
\hline 12 & $\mathrm{~F}$ & 30 & SDHD & $\begin{array}{c}\text { Exon 1, c. } 33 \mathrm{C}>\mathrm{A} \text {, } \\
\text { p. C11X } \\
\text { Nonsense } \\
\end{array}$ & No & Posterior mediastinum & $\mathrm{N}$ & Yes & $\begin{array}{c}\text { Yes } \\
\text { HNP, abdomen } \\
\text { extraadrenal } \\
\end{array}$ & ND & ND & No \\
\hline 13 & $\mathrm{~F}$ & 33 & SDHD & $\begin{array}{c}\text { Exon 1, c. } 33 \mathrm{C}>\mathrm{A}, \\
\text { p. } C 11 \mathrm{X}\end{array}$ & No & $\begin{array}{l}\text { Middle mediastinum } \\
\text { (aortopulmonary } \\
\text { window) }\end{array}$ & $0.7 \times 0.6$ & No & $\begin{array}{l}\text { Yes } \\
\text { HNP }\end{array}$ & Negative & Negative & No \\
\hline 14 & $\mathrm{~F}$ & 52 & SDHD & $\begin{array}{c}\text { Exon 1, c. } 33 \mathrm{C}>\mathrm{A} \text {, } \\
\text { p. C11X } \\
\text { Nonsense }\end{array}$ & $? ?$ & $\begin{array}{l}\text { Middle mediastinum } \\
\text { (between aortic arch, } \\
\text { right pulmonary artery, } \\
\text { VCS, trachea) }\end{array}$ & $5.2 \times 4.7$ & Yes & $\begin{array}{l}\text { Yes } \\
\text { HNP }\end{array}$ & ND & ND & No \\
\hline 15 & M & 22 & SDHB & $\begin{array}{c}\text { Exon 6, C.708T>C } \\
\text { (int. 574 T>C), } \\
\text { p. C192R } \\
\text { Missense }\end{array}$ & Yes & $\begin{array}{l}\text { Posterior mediastinum } \\
\text { Th8-Th11 }\end{array}$ & $\mathrm{N}$ & Yes & $\begin{array}{l}\text { Yes } \\
\text { HNP }\end{array}$ & Positive & Positive & Yes \\
\hline 16 & M & 40 & SDHD & $\begin{array}{c}\text { Exon 1, c.33C>A, } \\
\text { p. C11X } \\
\text { Nonsense }\end{array}$ & No & $\begin{array}{l}\text { Middle mediastinum } \\
\text { (between aortic bulb, } \\
\text { LAD and LA) }\end{array}$ & $3.5 \times 2$ & No & $\begin{array}{l}\text { Yes } \\
\text { HNP }\end{array}$ & ND & ND & No \\
\hline
\end{tabular}

ND - not done, VCS - venae cave superior, LA - left atrium, LAD - left descending artery, RCA - right coronary artery, HNP - head and neck paraganglioma, pheo pheochromocytoma, $\mathrm{N}$ - no data are available, only histological outcome 

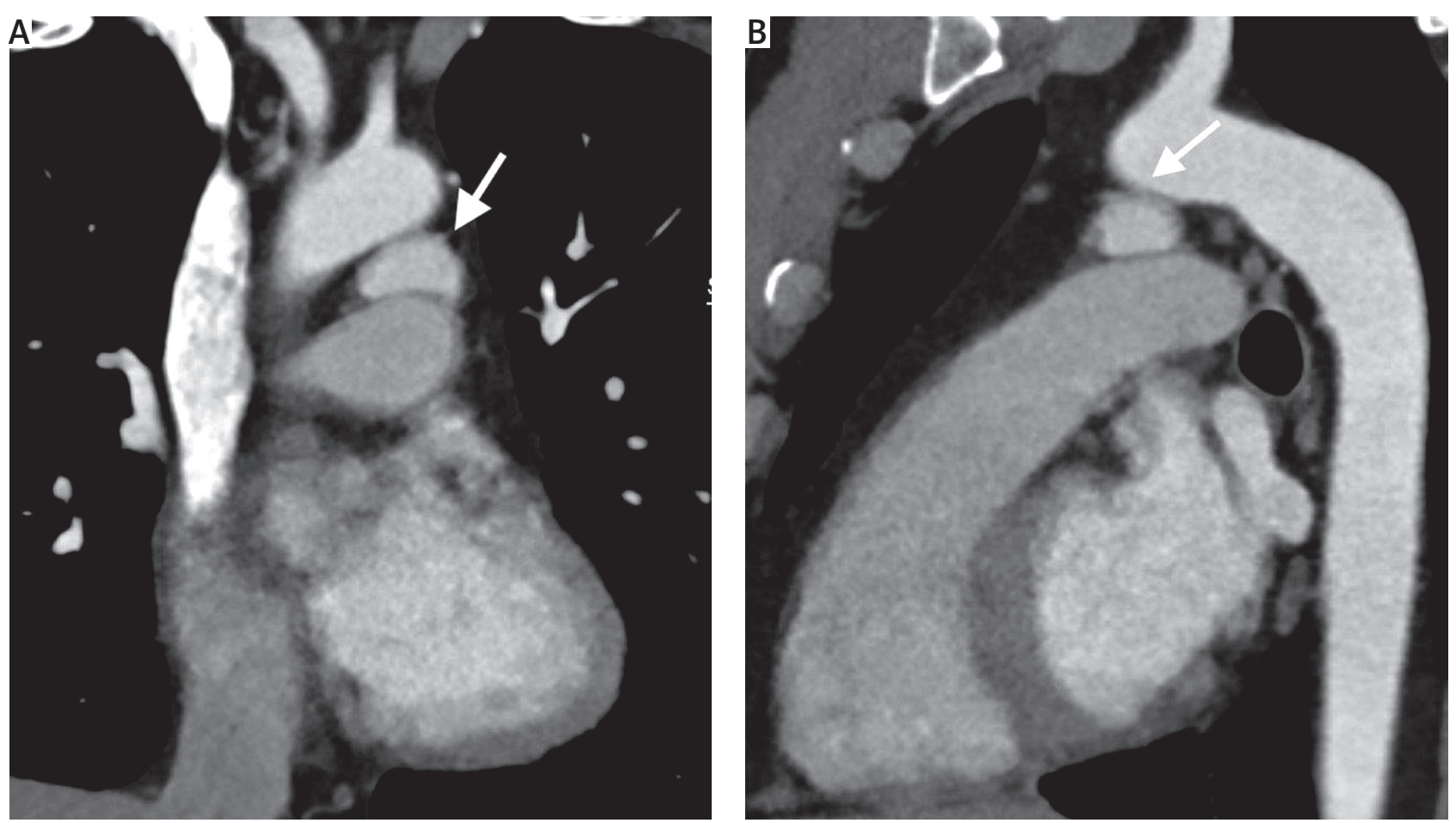

Fig. 1. Contrast-enhanced chest CT, multiplanar reconstruction (MPR): A - coronal view, B - sagittal view. Images show a hypervascular tumor in the aortopulmonary window (arrows)

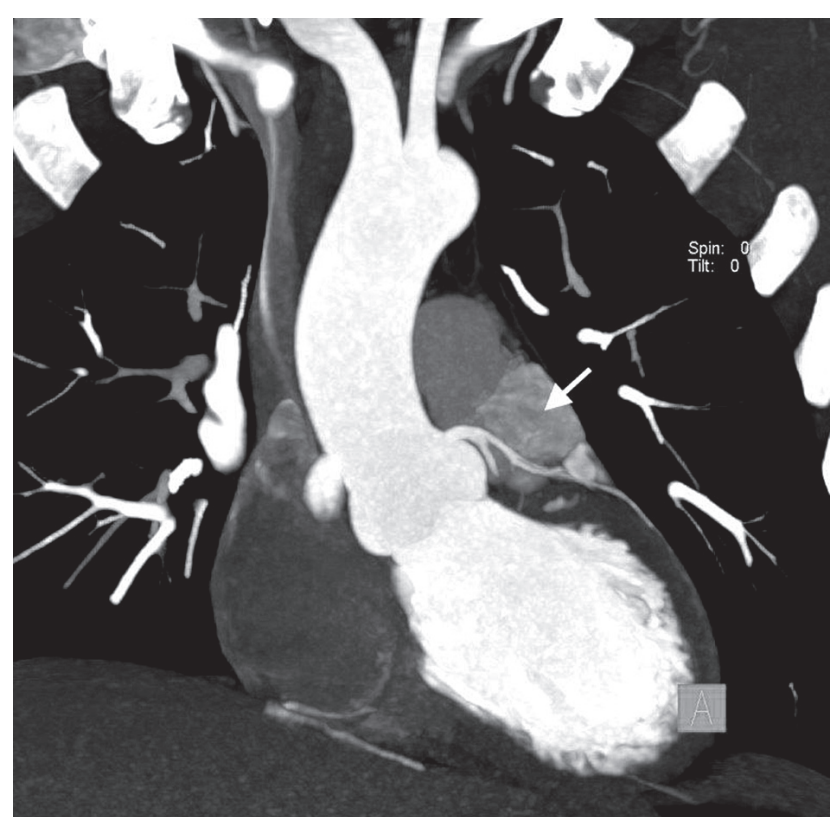

Fig. 2. Contrast-enhanced chest CT, maximum intensity projection (MIP) coronal view shows a hypervascular tumor located near the left descending artery (LAD) (arrow)

were confirmed in histopathological examinations as paragangliomas. Remaining patients (50\%) were treated conservatively.

\section{Follow-up}

All the patients who underwent surgery were followed up with CT. The median follow-up was 50 months (range:

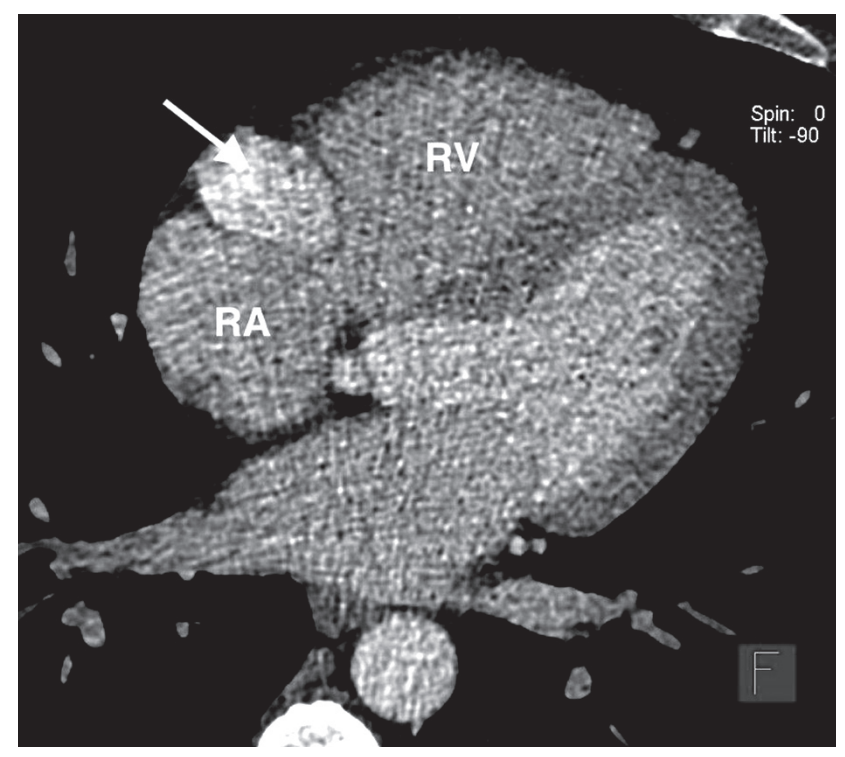

Fig. 3. Cardiac CT angiography, multiplanar reconstruction (MPR) axial view shows a hypervascular tumor located in the right atrioventricular groove (arrow)

$\mathrm{RA}$ - right atrium, RV - right ventricle

24-204 months). During the follow-up, none of the surgically treated patients had a residual tumor or developed metastatic diseases. One SDHB gene mutation carrier had a metastatic disease at the time of the diagnosis of a posterior mediastinal paraganglioma.

Eight patients treated conservatively underwent followup examinations. 


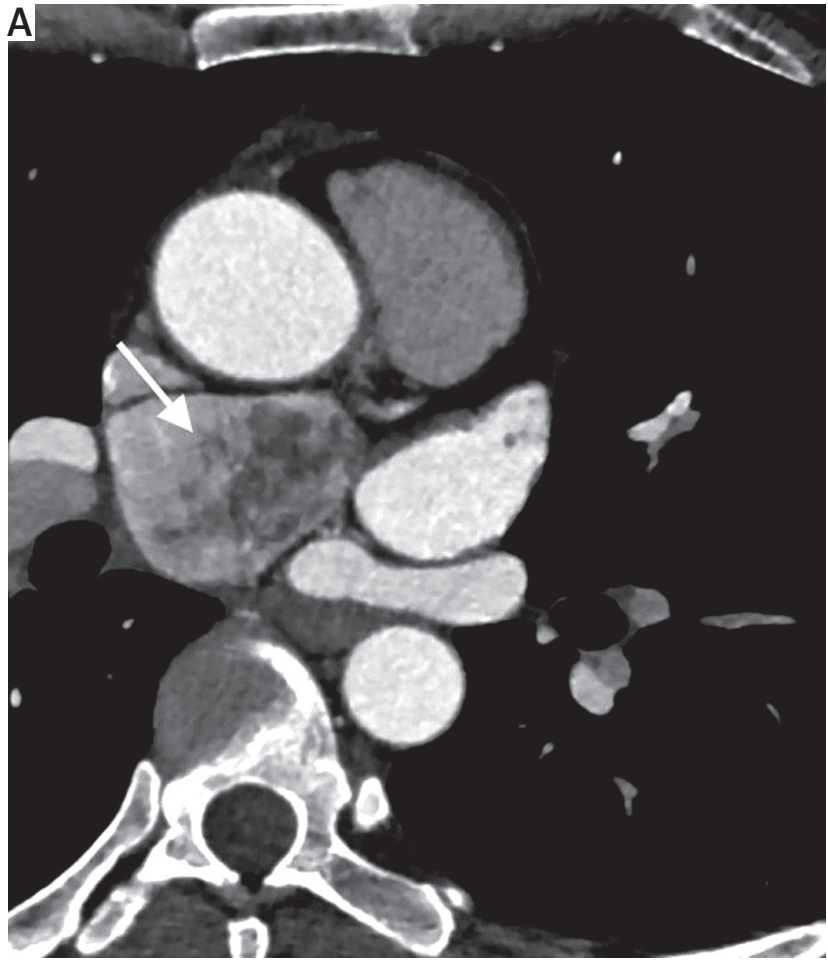

The median follow-up was 61 months (range: 13-74 months). None of the conservatively treated patients developed metastatic diseases.

\section{Discussion}

Paragangliomas related to $S D H x$ gene mutations are mainly localized in the head and neck region, and extraadrenally in the abdomen [18-20]. The mediastinum is a rare localization of paragangliomas; only $2 \%$ of all PGLS are found there [6]. The largest studies of mediastinal paragangliomas were based on the Mayo Clinic experience (14 patients) and the report of Martucci et al. (a multi-institutional study that included 15 patients) [21, 22]. Their findings similar to Ghayee underline that mediastinal paragangliomas are closely related to $\mathrm{SDH} x$ mutations and are often malignant [6].

Importantly, most patients in those reports had symptoms associated with catecholamine hypersecretion or cardiac-related symptoms of chest pain and/or shortness of breath [21, 22].

Nowadays due to extensive use of diagnostic chest imaging, some paragangliomas are diagnosed incidentally.

Furthermore, genetic counseling recommended to PGL families and the subsequent screening of carriers by anatomical imaging techniques have led to the detection of small paragangliomas, which can be localized in the mediastinum.

Our study represents a different group of patients with mediastinal paragangliomas than that in previous reports [21, 22]. All patients were carriers of SDHx mutations, and the majority of our patients underwent a CT evaluation of

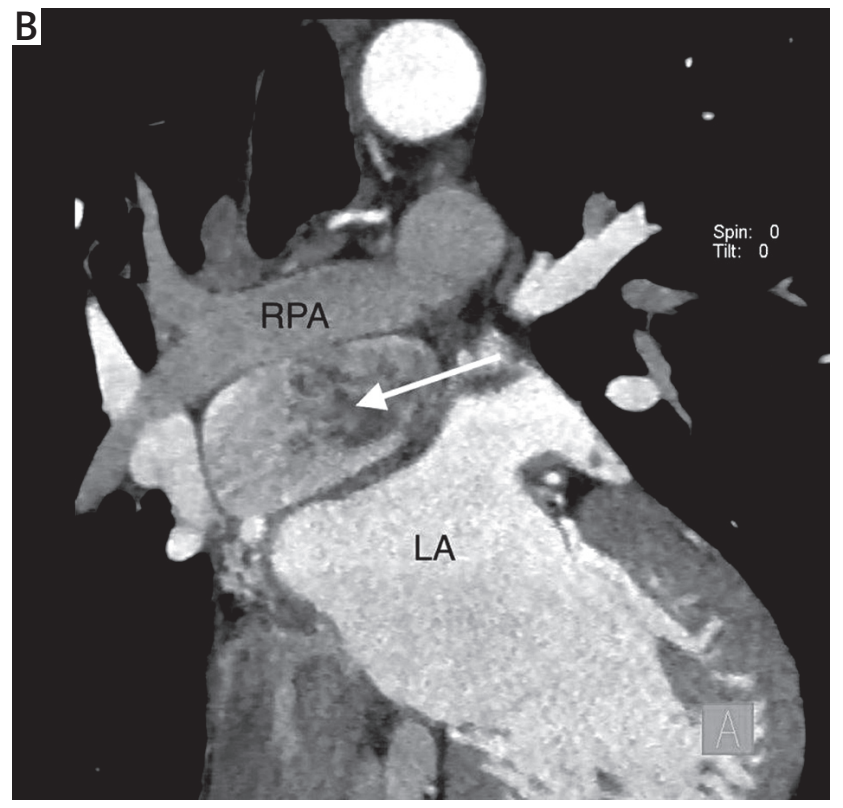

Fig. 4. Contrast-enhanced chest $\mathrm{CT}$, multiplanar reconstruction (MPR), A - axial view, B - coronal view, shows a mediastinal tumor adjacent to the ascending aorta, left atrium (LA), vena cava superior and right pulmonary artery (RPA) (arrows)

the chest as a screening test after detecting $S D H x$ gene mutations.

We found that the prevalence of mediastinal PGLs may be higher in carriers of $S D H x$ mutations than previously reported [6], especially in SDHD gene mutations. However, the majority of patients were asymptomatic.

Among 75 patients with SDHx gene mutations, 16 (21\%) patients had paragangliomas located in the mediastinum, but only 3 patients (with paragangliomas located in the posterior mediastinum) had symptoms associated with catecholamine hypersecretion, while the remaining patients were asymptomatic.

Surgical treatment remains a preferred method of treatment for paragangliomas.

Complete resection of the tumors is demanding due to their highly vascular nature and anatomical position, especially the proximity to major vessels or coronary arteries [11]. Surgical resection is often complicated by excessive hemorrhage and reconstruction of the surrounding structures [23]. In cases of a paraganglioma invasion into the heart, coronary arteries or other great vessels, a cardiopulmonary bypass should be employed [21]. A careful preoperative assessment of the tumor location is crucial and determines the surgical approach. Incomplete resection and high perioperative mortality (5.3\% to 9\%) have been reported [8, 24]. Using ECG gated CT in patients with suspected PGL located intracardially or intrapericardially significantly improves the image quality [22].

Paragangliomas located in head and neck regions are slowly growing tumors [25], and mediastinal paragangliomas seem to be slowly growing too. 
In chosen cases when a tumor is asymptomatic and surgical treatment is not an option due to its location, conservative treatment and follow-up may be considered.

In our report, the prevalence of mediastinal paragangliomas was higher (8.2\%) than in other reports, mainly due to $S D H D$ gene mutations and with a benign course [6]. None of the conservatively or surgically treated patients developed metastatic diseases. Only one SDHB carrier had a malignant $\mathrm{PGL}$.

It should be emphasized that almost all of our SDHD patients harbor one type of mutation. It is SDHD p.C11X, which was recognized as a Polish founder mutation [16]. The high frequency of mediastinal tumors in our group may de facto reflect the risk profile of that particular mutation.

\section{Conclusions}

Most mediastinal paragangliomas were related to SDHD gene mutations, were asymptomatic, and were localized intrapericardially. None of the PGLs related to SDHD mutations were malignant, and during the follow-up no metastases were detected.

Mediastinal PGLs were associated with other localizations, mainly in the head and neck region. Only one mediastinal PGL related to SDHB mutation was malignant.

The results of our study show that the prevalence of mediastinal paragangliomas in asymptomatic SDHx mutation carriers may be higher than previously believed.

\section{Funding}

This work was supported by a grant from the Institute of Cardiology in Warsaw, Poland (grant no. 2.4/II/14).

\section{Disclosure}

Authors report no conflict of interest.

\section{References}

1. Lenders JW, Duh QY, Eisenhofer G, Gimenez-Roqueplo AP, Grebe SK, Murad $\mathrm{MH}$, Naruse M, Pacak K, Young WF Jr. Pheochromocytoma and paraganglioma: an endocrine society clinical practice guideline. Endocrine Society. J Clin Endocrinol Metab 2014; 99: 1915-1942.

2. Baysal BE, Ferrell RE, Willett-Brozick JE, Lawrence EC, Myssiorek D, Bosch A, van der Mey A, Taschner PE, Rubinstein WS, Myers EN, Richard CW 3rd, Cornelisse CJ, Devilee P, Devlin B. Mutations in SDHD, a mitochondrial complex II gene, in hereditary paraganglioma. Science 2000; 28: 7848-7851.

3. Schiavi F, Boedeker CC, Bausch B, Peczkowska M, Gomez CF, Strassburg T, Pawlu C, Buchta M, Salzmann M, Hoffmann MM, Berlis A, Brink I, Cybulla M, Muresan M, Walter MA, Forrer F, Välimäki M, Kawecki A, Szutkowski Z, Schipper J, Walz MK, Pigny P, Bauters C, Willet-Brozick JE, Baysal BE, Januszewicz A, Eng C, Opocher G, Neumann HP. Predictors and prevalence of paraganglioma syndrome associated with mutations of the SDHC gene. J Am Med Assoc 2005; 294: 2057-2063.

4. Benn DE, Robinson BG, Clifton-Bligh RJ. 15 years of paraganglioma: clinical manifestations of paraganglioma syndromes types 1-5. Endocr Relat Cancer 2015; 22: 91-103.

5. Neumann HP, Pawlu C, Peczkowska M, Bausch B, McWhinney SR, Muresan M, Buchta M, Franke G, Klisch J, Bley TA, Hoegerle S, Boedeker CC, Opocher G, Schipper J, Januszewicz A, Eng C. Distinct clinical features of paraganglioma syndromes associated with SDHB and SDHD gene mutations. JAMA 2004; 292: 943-951.
6. Ghayee HK, Havekes B, Corssmit EP, Eisenhofer G, Hammes SR, Ahmad Z, Tessnow A, Lazúrová I, Adams KT, Fojo AT, Pacak K, Auchus RJ. Mediastinal paragangliomas: association with mutations in the succinate dehydrogenase genes and aggressive behavior. Endocr Relat Cancer 2009; 16: 291-299.

7. Qedra N, Kadry M, Buz S, Meyer R, Ewert P, Hetzer R. Aorticopulmonary paraganglioma with severe obstruction of the pulmonary artery: successful combined treatment by stenting and surgery. Ann Thorac Surg 2009; 87: 1284-1286.

8. Lack EE, Stillinger RA, Colvin DB, Groves RM, Burnette DG. Aortico-pulmonary paraganglioma: report of a case with ultrastructural study and review of the literature. Cancer 1979; 43: 269-278.

9. Juanpere S, Cańete N, Ortuńo P, Martínez S, Sanchez G, Bernado L. A diagnostic approach to the mediastinal masses. Insights Imaging 2013; 4: 29-52.

10. Cabral FC, Trotman-Dickenson B, Madan R. Hypervascular mediastinal masses: action points for radiologists. Eur J Radiol 2015; 84: 489-498.

11. Ayala-Ramirez M, Feng L, Johnson MM, Ejaz S, Habra MA, Rich T, Busaidy N, Cote GJ, Perrier N, Phan A, Patel S, Waguespack S, Jimenez C. Clinical risk factors for malignancy and overall survival in patients with pheochromocytomas and sympathetic paragangliomas: primary tumor size and primary tumor location as prognostic indicators. J Clin Endocrinol Metab 2011; 96: 717-725.

12. Wald O, Shapira OM, Murar A, Izhar U. Paraganglioma of the mediastinum: challenges in diagnosis and surgical management. J Cardiothorac Surg 2010; 5: 19.

13. Michalowska I, Cwikla JB, Pęczkowska M, Furmanek MI, Buscombe JR, Michalski W, Prejbisz A, Szperl M, Malinoc A, Moczulski D, Szutkowski Z, Kawecki A, Antoniewicz J, Pęczkowski P, Lewczuk A, Otto M, Cichocki A, Bednarek-Tupikowska G, Kabat M, Janaszek-Sitkowska H, Przybyłowska K, Janas J, Neumann HP, Januszewicz A. Usefulness of somatostatin receptor scintigraphy (99mTc-[HYNIC, Tyr3]-octreotide) and 1231-metaiodobenzylguanidine scintigraphy in patients with SDHx gene-related pheochromocytomas and paragangliomas detected by computed tomography. Neuroendocrinology 2015; 101: 321-330.

14. Milardovic R, Corssmit EP, Stokkel M. Value of 123I-MIBG scintigraphy in paraganglioma. Neuroendocrinology 2010; 91: 94-100.

15. Sahdev A, Sohaib A, Monson JP, Grossman AB, Chew SL, Reznek RH. CT and MR imaging of unusual locations of extra-adrenal paragangliomas (pheochromocytomas). Eur Radiol 2005; 15: 85-92.

16. Pałasz P, Adamski $Ł$, Studniarek M. Paragangliomas: a propos of two cases. Diagnostics and treatment. Pol J Radiol 2015; 80: 411-416.

17. Tischler AS. Pheochromocytoma and extra-adrenal paraganglioma: updates. Arch Pathol Lab Med 2008; 132: 1272-1284.

18. Decristoforo C, Melendez-Alafort L, Sosabowski JK, Mather SJ. 99mTc-HYNIC-[Tyr3]-octreotide for imaging somatostatin-receptor-positive tumors: preclinical evaluation and comparison with 111In-octreotide. J Nucl Med 2000; 41: 1114-1119.

19. Peczkowska M, Erlic Z, Hoffmann MM, Furmanek M, Cwikla J, Kubaszek A, Prejbisz A, Szutkowski Z, Kawecki A, Chojnowski K, Lewczuk A, Litwin M, Szyfter W, Walter MA, Sullivan M, Eng C, Januszewicz A, Neumann HP. Impact of screening kindreds for SDHD p.Cys11X as a common mutation associated with paraganglioma syndrome type 1. J Clin Endocrinol Metab 2008; 93: 4818-4825.

20. Peczkowska M, Cascon A, Prejbisz A, Kubaszek A, Cwikła BJ, Furmanek M, Erlic Z, Eng C, Januszewicz A, Neumann HP. Extra-adrenal and adrenal pheochromocytomas associated with a germline SDHC mutation. Nat Clin Pract Endocrinol Metab 2008; 4: 111-115.

21. Brown ML, Zayas GE, Abel MD, Young WF Jr, Schaff HV. Mediastinal paragangliomas: the mayo clinic experience. Ann Thorac Surg 2008; 86: 946-951.

22. Martucci VL, Emaminia A, del Rivero J, Lechan RM, Magoon BT, Galia A, Fojo T, Leung S, Lorusso R, Jimenez C, Shulkin BL, Audibert JL, Adams KT, Rosing DR, Vaidya A, Dluhy RG, Horvath KA, Pacak K. Succinate dehydrogenase gene mutations in cardiac paragangliomas. Am J Cardiol 2015; 115: 1753-1759.

23. Khan MF, Datta S, Chisti MM, Movahed MR. Cardiac paraganglioma: clinical presentation, diagnostic approach and factors affecting short and long-term outcomes. Int J Cardiol 2013; 166: 315-320.

24. Lamy AL, Fradet GJ, Luoma A, Nelems B. Anterior and middle mediastinum paraganglioma: complete resection is the treatment of choice. Ann Thorac Surg 1994; 57: 249-252.

25. Langerman A, Athavale SM, Rangarajan SV, Sinard RJ, Netterville JL. Natural history of cervical paragangliomas: outcomes of observation of 43 patients. Arch Otolaryngol Head Neck Surg 2012; 138: 341-345. 